CAKRAWALA LINGUISTA

e-ISSN: 2597-9779 dan p-ISSN: 2597-9787

This work is licensed under

a Creative Commons Attribution-NonCommercial 4.0 International License.

\title{
Increasing Ability to Understand Fairy Tale Through Directed Reading Thinking Activity (DRTA) Strategy
}

\author{
Titin Setiartin ${ }^{1}$ \\ Universitas Siliwangi, Tasikmalaya, Indonesia ${ }^{1}$ \\ E-mail: setiar_tin@hotmail.com
}

\section{Keywords : \\ Understanding Fairy Tales; Thinking Strategies; Directed Reading Thinking Activity (DRTA)}

\section{ABSTRACT}

The DRTA strategy is basically designed for group reading teaching. This strategy has received great attention from language teachers over the last two decades because of its ease and emphasis on developing high-minded processes. In addition, DRTA involves an active understanding and exchange of ideas among learners. Effective also in directing the social dynamics of learning groups of learners. Individual and group predictions about the content of reading are developed on the basis of individual backgrounds and information contained in the text. This strategy requires teachers to create hypotheses and make predictions about the content of the reading. Group dynamics will generate predictions and provide opportunities for learners to link these predictions with reading content. The purpose of this study is to describe the effectiveness of DRTA strategy in reading comprehension learning; describe the improvement of the ability of learners in reading fairy tales. The result of the research can be known based on the gain index of the initial and final test of the experimental class and control class, there is an increasing difference between the learning by using DRTA strategy and the learning using conventional strategy from percentage gain improvement in the experimental class higher than the control class. While the gain index of the experimental class is 0.57 (including the medium category) with the lesson using the DRTA strategy and for the control class with the gain index of 0.45 (including the medium category) with the reading comprehension learning conventional strategy. From the difference of gain, index can be concluded that there is a difference of understanding between learners who learn by using DRTA strategy with students who study conventionally. Between the two experimental classes, the average value of learners who learn to use DRTA is higher than that of learners who learn to use conventional learning. Constructivists view that learning is a process of assimilating and connecting the experience or material learned with the understanding it has for the understanding to develop. 


\section{INTRODUCTION}

Primary school education aims to provide basic skills of basic literacy, knowledge, and basic skills that are useful for learners in accordance with their level of development. Furthermore, to prepare them for junior secondary education. Related to the purpose of providing basic literacy skills, the role of Indonesian language teaching in elementary school relies on basic literacy skills. Learning is not only in the stage of discourse (in the early grades) but also in the achievement of the high-end (highclass).

Reading is a skill to improve one's reasoning power. This means that one's thinking power is determined by the culture of reading it. By macro, reading also has an impact on the quality of nation and state development (the advancement of a country depends on the interest and culture of reading).

We have seen that the product of reading activity is communication, which is the definition of the reader on the ideas presented by the author in the form of print. Now we can know that the wealth of knowledge can now be obtained by people living today because we can already read things they wrote in the past. (Harjasujana and Damaianti, 2003: 41)

The low interest in reading is the main problem facing our nation. This is evident from the lagging quality of our human resources by neighboring countries, and it shows our quality of education is lower than they are. One is the result of very low reading habits and this is fatal to the quality of one's own human resources, for one's intelligence power, one of the keys is determined by the frequency and number of books he/she reads (reading culture).

The DRTA strategy is basically designed for group reading teaching. This strategy has received great attention from language teachers over the last two decades because of its ease and emphasis on developing high-minded processes. In addition, DRTA involves an active understanding and exchange of ideas among learners and is very effective in directing the social dynamics that occur within the group of learners.

Individual and group predictions about the content of the reading are developed on the basis of individual backgrounds and information provided by the text. This strategy requires teachers to create hypotheses and make predictions about the content of the reading. Group dynamics will generate predictions and provide opportunities for learners to link predictions with reading content.

\section{METHOD}

The study was conducted three times (PI, PII, and PIII). Each meeting uses a different fairy tale. Assessment of learning outcomes reading with DRTA strategy in accordance with indicators of achievement of learning outcomes consists of three, (1) finding the key thoughts contained in the text, (2) compiling a summary, and (3) explaining the content of the text with sentences. All of that is classified into a group of assessment criteria from less, enough, and well. The data from the learning outcomes were analyzed by converting the criteria less $(\mathrm{L})$ to score 1 , enough criteria $(\mathrm{F})$ to score 2 , and good criterion $(\mathrm{G})$ to score 3, then looking for the average score and percentage of student learning outcomes in reading with DRTA strategy. Criterion of learning outcomes by using a scale of 100 with the following categories. Assessment Criteria according to Suherman (2001).

a. Good $=2.45-3.0(81.7 \%-100 \%)$

b. Fair $=1.45-2.44(48.3 \%-81.3 \%)$

c. Less $=0.0-1.44(0 \%-48 \%)$ 
Table I

Assessment Indicator

\begin{tabular}{|c|c|c|c|c|}
\hline \multirow{2}{*}{ No } & \multirow{2}{*}{ Indicator } & \multicolumn{3}{|c|}{ Criteria of Learning Outcomes D1 } \\
\hline & & $\mathbf{L}$ & $\mathbf{F}$ & $\mathbf{G}$ \\
\hline 1. & \multicolumn{4}{|l|}{$\begin{array}{l}\text { Find the main points of thought } \\
\text { contained in the text }\end{array}$} \\
\hline 2. & \multicolumn{4}{|l|}{$\begin{array}{l}\text { Explain the contents of the text with a } \\
\text { sentence }\end{array}$} \\
\hline 3. & \multicolumn{4}{|l|}{ Make a summarize } \\
\hline \multirow{2}{*}{ No } & \multirow{2}{*}{ Indikator } & \multicolumn{3}{|c|}{ Criteria of Learning Outcomes D2 } \\
\hline & & $\mathbf{L}$ & $\mathbf{F}$ & $\mathbf{G}$ \\
\hline 1. & \multicolumn{4}{|l|}{$\begin{array}{l}\text { Find the main points of thought } \\
\text { contained in the text }\end{array}$} \\
\hline 2. & \multicolumn{4}{|l|}{$\begin{array}{l}\text { Explain the contents of the text with a } \\
\text { sentence }\end{array}$} \\
\hline 3. & \multicolumn{4}{|l|}{ Make a summarize } \\
\hline \multirow{2}{*}{ No } & \multirow{2}{*}{ Indicator } & \multicolumn{3}{|c|}{ Criteria of Learning Outcomes D3 } \\
\hline & & $\mathbf{L}$ & $\mathbf{F}$ & G \\
\hline 1. & $\begin{array}{l}\text { Find the main points of thought } \\
\text { contained in the text }\end{array}$ & & & \\
\hline 2. & $\begin{array}{l}\text { Explain the contents of the text with a } \\
\text { sentence }\end{array}$ & & & \\
\hline 3. & Make a summarize & & & \\
\hline
\end{tabular}

Description:

D1 = The Tale entitled "Spiders, Rabbits and the Moon"

D2 = Tale entitled "The Meaning of a Friendship"

D3 = Tale entitled "An Efficient Ant"

$\mathrm{L}=$ Less

$\mathrm{F}=$ Fair

$\mathrm{G}=\mathrm{Good}$

The results of the students who have been analyzed and grouped into several assessment criteria, so that the students' outcomes in the understanding of fairy tales, and to see the improvement of the students' results on reading learning with DRTA strategy at the first meeting, and the students' results on reading learning at the second meeting. The results of the percentage of student results are presented in Table I. To see the improvement of student learning outcomes, the results of the analysis are presented in Table II.

Table II

Presentation of Data Improving Student Learning Outcomes in Reading

\begin{tabular}{|l|l|c|c|c|c|c|}
\hline \multirow{2}{*}{ No } & \multicolumn{1}{|c|}{ Indicator } & \multicolumn{2}{|c|}{$\begin{array}{c}\text { Average of Student } \\
\text { Learning Results }\end{array}$} & \multirow{2}{*}{ Average } & \multirow{2}{*}{ Category } \\
\cline { 3 - 4 } & & P I & P II & P III & & \\
\hline 1. & $\begin{array}{l}\text { Find the main points of thought } \\
\text { contained in the text }\end{array}$ & & & & & \\
\hline 2. & $\begin{array}{l}\text { Explain the contents of the text } \\
\text { with a sentence }\end{array}$ & & & & & \\
\hline 3. & Make a summarize & & & & & \\
\hline
\end{tabular}

Information:

Good Quite Less P = Learning Meetings

(Suherman, 2001)

\section{RESULTS AND DISCUSSIONS}

The development of science and technology demands the creation of a reading society. Reading people gain new knowledge and insights that will further enhance their intelligence so that they are better able to answer the challenges of life in the future.

Burn, et al (1996) suggests that the ability to read is vital in an educated society. However, children who do not understand the importance of learning to read will not be motivated to learn. Learning to 
read is an ongoing endeavor, and children who see the high value (reading) in their personal activities will be more active learning than children who do not find the benefits of reading.

Conduct reading activities by utilizing all the mental capacity it has to gain meaning (understanding) of the material it reads.

The process of understanding in reading has levels. Burns et al (1984: 177) suggest a level of understanding divided into:

a. Literal understanding

b.Interpretive understanding

c. Critical understanding

d.Creative understanding

Achieving each level of understanding are known three reading techniques called reading on the line, reading between the lines, and reading outside the line. The technique of reading on lines can be used to gain literal understanding, the technique of reading between lines to gain interpretive and critical understanding. While reading techniques outside the line generally used to gain an appreciation of understanding.

Making predictions about what will happen in a text encourages children to think about text messages. In making predictions, students use a background of knowledge about the topic and their knowledge of the organizational patterns of the text, trying to confirm or reject its own. This step also encourages students to apply the students' metacognitive skills, because students think according to their own way of thinking. If the student has not been able to predict as required, the teacher can help. Indicators achieved or the actions of the learning outcomes include (1) finding the key thoughts contained in the text, (2) compiling a summary, and (3) explaining the content of the text with sentences.

Steps to read through the DRTA strategy:

a. Creating prediction based on title instructions

b. Make predictions from the image instructions

c. Reading the reading material

d. Assess precise accuracy and adjust predictions

e. Teacher repeats

Direct reading or activity thinking activities (DRTAs) actively encourage the reader to a comprehensive three-step series:

a. Simplify the text

b. Make predictions

c. Simplify text to strengthen or justify previous predictions.

Using DRTA, teachers give students a choice of text and ask them to read the title. Few examples of text and images used to develop hypotheses about the text. Children generally provide what hypotheses are read from the text and from the background of their own experiences.

Teachers may adopt DRTA as an example of the most important element of narrative or exposition based on text structure, if children are assigned a narrative or story to read, the DRTA can be based on the most important element of the story's vocabulary, or the map as suggested by Beck \& McKeown ( $1981)$ "This element consists of setting, character, initial event, problem, problem solving or solution".

The Directed Reading Thinking Activity (DRTA) strategy motivates and concentrates students in reading and engaging students to think intellectually about intellectual tales and encourage students to formulate questions and hypotheses. The teacher gives the students a fairy tale and asks them to read the title and use the picture in a fairy tale. Implementation of the Direct Reading Thinking Activity (DRTA) strategy in classroom teaching, with the steps students, make predictions based on title instructions, make predictions from the drawing instructions, read the reading material, assess the 
accuracy of predictions and adjust predictions, and teachers repeat procedures one through four until all the above lessons have been covered.

At each stopping place, the teacher repeats step four. Finally, the teacher asks students to make a summary of the story according to their respective versions. DRTA strategy with fictional reading material can be continued by asking the values contained in the story, perhaps various responses given by the students. The expected learning outcomes are understanding the text and composing the framework, the indicators of whether or not the learning outcomes include (1) finding the key thoughts in the text, (2) compiling the summary, and (3) explaining the text content with sentences.

Assessment of learning outcomes reading with DRTA strategy in accordance with indicators of achievement of learning outcomes consists of three, (1) finding the main points of thought contained in the text, (2) compiling a summary, and (3) explaining the content of the text with sentences. All of that is classified into group of assessment criteria from less, enough, and well. The data from the learning outcomes were analyzed by converting the criteria less $(\mathrm{L})$ to score 1 , enough criteria $(\mathrm{F})$ to score 2 , and good criterion $(\mathrm{G})$ to score 3 , then looking for the average score and percentage of student learning outcomes in reading with DRTA strategy.

Assessment Criteria according to Suherman (2001)

$$
\begin{aligned}
& \text { Good }=2.45-3.0(81.7 \%-100 \%) \\
& \text { Fair }=1.45-2.44(48.3 \%-81.3 \%) \\
& \text { Less }=0.0-1.44(0 \%-48 \%)
\end{aligned}
$$

\begin{tabular}{|c|c|c|c|c|}
\hline \multirow{2}{*}{ No } & \multirow{2}{*}{ Indicator } & \multicolumn{3}{|c|}{ Criteria of Learning Outcomes D1 } \\
\hline & & $\mathbf{L}$ & $\mathbf{F}$ & G \\
\hline 1. & $\begin{array}{l}\text { Find the main points of thought } \\
\text { contained in the text }\end{array}$ & $\begin{array}{l}15 \text { Students } \\
(46,9 \%)\end{array}$ & $\begin{array}{l}5 \text { Students } \\
(15,6 \%)\end{array}$ & $\begin{array}{l}12 \text { Students } \\
(37,5 \%)\end{array}$ \\
\hline 2. & $\begin{array}{l}\text { Explain the contents of the text with } \\
\text { a sentence }\end{array}$ & $\begin{array}{l}15 \text { Students } \\
(46,9 \%)\end{array}$ & $\begin{array}{l}5 \text { Students } \\
(15,6 \%)\end{array}$ & $\begin{array}{l}12 \text { Students } \\
(37,5 \%)\end{array}$ \\
\hline 3. & Make a summarize & $\begin{array}{l}\text { O Student } \\
(0,0 \%)\end{array}$ & $\begin{array}{l}15 \text { Students } \\
(46,9 \%)\end{array}$ & $\begin{array}{l}17 \text { Students } \\
(53,1 \%)\end{array}$ \\
\hline \multirow{2}{*}{ No } & \multirow{2}{*}{ Indicator } & \multicolumn{3}{|c|}{ Criteria of Learning Outcomes D2 } \\
\hline & & $\mathbf{L}$ & $\mathbf{F}$ & G \\
\hline 1. & $\begin{array}{l}\text { Find the main points of thought } \\
\text { contained in the text }\end{array}$ & $\begin{array}{l}3 \text { Students } \\
(9,4 \%)\end{array}$ & $\begin{array}{l}7 \text { Students } \\
(21,9 \%)\end{array}$ & $\begin{array}{l}22 \text { Students } \\
(68,8 \%)\end{array}$ \\
\hline 2. & $\begin{array}{l}\text { Explain the contents of the text with } \\
\text { a sentence }\end{array}$ & $\begin{array}{l}3 \text { Students } \\
(9,4 \%)\end{array}$ & $\begin{array}{l}7 \text { Students } \\
(21,9 \%)\end{array}$ & $\begin{array}{l}22 \text { Students } \\
(68,8 \%)\end{array}$ \\
\hline 3. & Make a summarize & $\begin{array}{l}\text { O Student } \\
(0,0 \%)\end{array}$ & $\begin{array}{l}\text { 4 Students } \\
(12,5 \%)\end{array}$ & $\begin{array}{c}28 \text { Students } \\
(87,5 \%)\end{array}$ \\
\hline \multirow{2}{*}{ No } & \multirow{2}{*}{ Indicator } & \multicolumn{3}{|c|}{ Criteria of Learning Outcomes D3 } \\
\hline & & $\mathbf{L}$ & $\mathbf{F}$ & $\mathbf{G}$ \\
\hline 1. & $\begin{array}{l}\text { Find the main points of thought } \\
\text { contained in the text }\end{array}$ & $\begin{array}{l}\text { O Student } \\
(0,0 \%)\end{array}$ & $\begin{array}{c}10 \text { Students } \\
(31,3 \%)\end{array}$ & $\begin{array}{l}22 \text { Students } \\
(68,8 \%)\end{array}$ \\
\hline 2. & $\begin{array}{l}\text { Explain the contents of the text with } \\
\text { a sentence }\end{array}$ & $\begin{array}{l}\text { O Student } \\
(0,0 \%)\end{array}$ & $\begin{array}{l}10 \text { Students } \\
(31,3 \%)\end{array}$ & $\begin{array}{l}22 \text { Students } \\
(68,8 \%)\end{array}$ \\
\hline 3. & Make a summarize & $\begin{array}{l}\text { O Student } \\
(0,0 \%)\end{array}$ & $\begin{array}{l}3 \text { Students } \\
(9,38 \%)\end{array}$ & $\begin{array}{c}29 \text { Students } \\
(90,6 \%)\end{array}$ \\
\hline
\end{tabular}

Table III

Percentage of Student Results in Learning

Description:

D1 = The Tale entitled "Spiders, Rabbits and the Moon"

D2 = Tale entitled "The Meaning of a Friendship"

D3 = Tale entitled "An Efficient Ant"

$\mathrm{L}=$ Less

$\mathrm{F}=$ Fair

$\mathrm{G}=\mathrm{Good}$

Student learning outcomes in reading learning with direct reading thinking (Directed Reading Thinking Activity (DRTA) is obtained through student activity in learning The result of students who have been analyzed and grouped into several assessment criteria, so that the students' and to see improvements in student outcomes in reading learning with the DRTA strategy at the first meeting, and student outcomes in reading learning at the second meeting The results of the percentage of student outcomes are presented in Table III. 
The data above shows that the increase in students in the learning results increased seen the number of students in each fairy tale has increased, to see how far the increase in student learning outcomes then the analysis results are presented in Table IV.

Table IV

Increasing Student Learning Outcomes in Reading

\begin{tabular}{|c|c|c|c|c|c|c|}
\hline \multirow[b]{2}{*}{ No } & \multirow{2}{*}{ Indicator } & \multicolumn{3}{|c|}{$\begin{array}{l}\text { Average of Student Learning } \\
\text { Results }\end{array}$} & \multirow[b]{2}{*}{ Average } & \multirow[b]{2}{*}{ Category } \\
\hline & & P I & P II & P III & & \\
\hline 1. & $\begin{array}{l}\text { Find the main points of } \\
\text { thought contained in } \\
\text { the text }\end{array}$ & $\begin{array}{c}1,89 \\
(59,1 \%)\end{array}$ & $\begin{array}{c}2,03 \\
(63,4 \%)\end{array}$ & $\begin{array}{c}2,25 \\
(70,3 \%)\end{array}$ & $\begin{array}{c}2,06 \\
(64,4 \%)\end{array}$ & Fair \\
\hline 2. & $\begin{array}{l}\text { Explain the contents of } \\
\text { the text with a sentence }\end{array}$ & $\begin{array}{c}1,67 \\
(52,2 \%)\end{array}$ & $\begin{array}{c}1,94 \\
(60,6 \%)\end{array}$ & $\begin{array}{c}2,6 \\
(81,3 \%)\end{array}$ & $\begin{array}{c}2,07 \\
(64,7 \%)\end{array}$ & Fair \\
\hline 3. & Make a summarize & $\begin{array}{c}2,17 \\
(67,8 \%)\end{array}$ & $\begin{array}{c}2,5 \\
(78,1 \%\end{array}$ & $\begin{array}{c}2,61 \\
(81,6 \%)\end{array}$ & $\begin{array}{c}2,43 \\
(75,9 \%)\end{array}$ & Fair \\
\hline
\end{tabular}

Description:

Good $=2.45-3.0(81.7 \%-100 \%)$

Fair $=1.45-2.44(48.3 \%-81.3 \%)$

Less $=0.0-1.44(0 \%-48 \%)$

$\mathrm{P}=$ Learning Meetings (Suherman, 2001)

Based on table 4.2 above, the average of the most dominant student learning outcomes is to compile a summary $(75.9 \%)$ with sufficient increment criteria, student learning outcomes in finding the points of thought contained in text $(64.4 \%)$ with criteria enough increase, then is the result of the students in explaining the content of the text with the sentence $(64.07 \%)$ with sufficient increase criteria.

Based on data analysis of research results, the use of DRTA strategy in reading comprehension has good potential to increase understanding of understanding fairy tale. This can be seen from the difference in the average increase in students' understanding on reading comprehension on the experimental class at meeting I (PI), meeting 2 (PII), and meeting 3 (PIII). Despite the less significant differences in the experimental class. However, it can be seen in improving learning outcomes to read learners' understanding. The average of the most dominant student learning outcomes is to compile a summary (75.9\%) with sufficient increase criteria. Students' learning outcomes in finding the thoughts found in the text $(64.4 \%)$ with sufficient increase criteria. Furthermore, the results of learning in explaining the content of the text with the sentence (64.07\%) with sufficient increase criteria.

\section{CONCLUSION}

Experience is an important aspect of the reading process. Children with extensive experience will have a wider opportunity to develop their understanding of the vocabulary and concepts they face in reading than children with limited experience. The concrete experience (direct experience) in the indirect experience will enhance the child's conceptual development. However, direct experience is more effective than indirect experience. Teachers and parents can help children learn a standard language commonly found in books by telling and reading stories, encouraging show and tell activities to encourage class discussions, using language experience through stories, and encouraging drama play.

Learning by using the Directed Reading Thinking Activity (DRTA) strategy and conventional learning can improve students' understanding of comprehension reading. Based on the gain index of the initial and final tests of the experimental class and control class, there is an increasing difference between the lessons using the DRTA strategy and the learning using the conventional strategy of percentage gain improvement in the experimental class higher than the control class. While the gain index of the experimental class is 0.57 (including the medium category) with the lesson using the DRTA strategy and for the control class with the gain index of 0.45 (including the medium category) with the reading comprehension learning conventional strategy. 
The most dominant student learning outcomes were to compile a summary (75.9\%) with sufficient increment criteria, the students' learning outcomes in finding the thoughts found in the text $(64.4 \%)$ with sufficient increment criteria, then the results students in explaining the content of the text with sentences $(64.07 \%)$ with sufficient increment criteria.

Learning with the DRTA strategy provides a positive response, in the sense that teachers feel that learning using the DRTA strategy has never applied in classroom learning, making predictions about drawings or story titles have been done, but in this DRTA learning the students should be able to express their predictions without which is binding, because the DRTA is not seen to be true or false of students 'expressed predictions, but arouses students' courage in expressing what they think. Teachers argue that students are very interested and happy with reading learning using the DRTA strategy. Proven when the learning time has been exhausted students still want to read and tell the tale that he read.

\section{REFERENCES}

Baried, St. B., dkk. (1985). Memahami Hikayat dalam Sastra Indonesia. Jakarta : Pusat Pembinaan dan Pengembangan Bahasa.

Bogdan, Robert C. dan Sari Knoop Biklen (1982) Qualitative Research for Education to Theory and Method, Boston: Allyn and Bacon Inc.

Brown, D. (2000). Principles of Language Learning and Teaching. San Fracisco: Longman.

Brown, D. (2001). Teaching By Prinsiple: An Interactive Approach to Language Pedagogy. San Fracisco: Longman.

Bloom, B. (1979). Taxonomy of Educational Objectives. Long Man: Group Ltd.

Bunanta. (2004). Buku, Mendongeng, dan Minat Membaca. Jakarta : Pustaka Tangga.

Burnes, D and Page, G. (1985). Insight and Strategies for Teaching Reading. Sidney: Harcourt Brace Javanovich Groups.

Burnes, Roe, and Ross. (1984). Teaching Reading in Today's Elementary Schools. New Jersey: Houghton Mifflin Company.

Cox, Carole. (1999). Teaching Language Arts (A Student and Response Centered Classroom). Long Beach: A Viacom Company.

Danandjaja, James. (2007). Folklor Indonesia. Jakarta : Graffiti Press

Endraswara, Suwardi. (2002). Metode Penelitian Psikologi Sastra. Teori, Langkah, dan Penerapannya. Yogyakarta: MedPress.

Fang, L.Y. (1991). Sejarah Kesusastraan Melayu Klasik. Jakarta: Erlangga.

Harjasujana, Ahmad Slamet dan Vismaia S. Damaianti. (2003). Membaca dalam Teori dan Praktik. Bandung: Mutiara.

Smith, Frank. (1985). Understanding Reading: A Psycholinguistic Analysis of Reading and Learning to Read. New York: Holt, Renehart, and Winston. 